УДК 159.9+340.11

DOI https://doi.org/10.26661/2310-4368/2021-1-8

\title{
МОДЕЛІ ФОРМУВАННЯ ПРАВОСВІДОМОСТІ МАЙБУТНІХ ФАХІВЦІВ ЮРИДИЧНОГО ПРОФІЛЮ
}

\author{
Кононенко С. В. \\ кандидат психологічних наук, дочент, \\ професор кафедри психології \\ Донеиький інститут \\ Міжрегіональної Академї управління персоналом \\ вул. Уральська, 12, Краматорськ, Донеиька область, Україна \\ orcid.org/0000-0003-0146-4846 \\ kononenko-sv-@ukr.net
}

\begin{abstract}
Ключові слова: особистість спечіаліста юридичного профілю, свідомість, правосвідомість, діяльність майбутніх юристів, моделі формування правосвідомості, професійна правосвідомість.
\end{abstract}

У роботі розглядаються особливості методологічних підходів, розробки моделей формування правосвідомості майбутніх фахівців юридичного профілю, підходи, згідно з якими становлення і розвиток правосвідомості майбутніх юристів здійснюються 3 урахуванням загальної закономірності функціонування і розвитку людини. Аналізується професійний та особистий розвиток майбутнього юриста в умовах вищого навчального закладу, який мав би мати розбіжність на різних курсах, оскільки характер взаємодій між структурними компонентами правосвідомості юриста на різних етапах навчання має свою специфіку.

Головну увагу при вирішенні проблеми розвитку правосвідомості спрямовано на розкриття ऑiі сутності, структури, внутрішньої організації, взаємозв' язку компонентів, іії інтеграційну систему чинників; механізмів, що забезпечують цілісність системи виявлення етапів, тенденцій і перспектив iii розвитку. Розвиток правової свідомості визначається типологією і специфікою професійно зумовлених завдань, загальним рівнем розвитку правової свідомості студентів, що впливає на ефективність навчальної та майбутньої професійної діяльності.

Свідомість юриста різниться залежно від досвіду юридичної діяльності та особистісних характеристик (активність, емоційно-вольова сфера, мотивація досягнення успіху, інтернальність, рефлексивність, інтелект). Особливості вияви суб'єктності у професійній діяльності юриста зумовлені змістом Я-концепції. Таким чином, формування особистості юриста-не тільки мета, але і найважливіша умова розвитку правосвідомості майбутніх фахівців. Розвиток правосвідомості є закономірним процесом змін, виражених у кількісних, якісних і структурних перетвореннях особистості, а психологічні умови розвитку правосвідомості майбутніх юристів - це сукупність заходів в освітньому процесі, які забезпечують досягнення майбутніми фахівцями необхідного рівня правосвідомості. 


\title{
THE FORMATION MODELS OF LEGAL CONSCIOUSNESS OF WOULD-BE LEGAL PROFESSIONALS
}

\author{
Kononenko S. V. \\ Candidate of Psychological Sciences, Associate Professor, \\ Professor at the Department of Psychology \\ Donetsk Institute \\ of the Interregional Academy of Personnel Management \\ Uralska str., 12, Kramatorsk, Donetsk region, Ukraine \\ orcid.org/0000-0003-0146-4846 \\ kononenko-sv-@ukr.net
}

Key words: personality of a legal specialist, consciousness, legal consciousness, activities of would-be lawyers, formation model of legal consciousness, professional legal consciousness.
This paper examines particulars of the methodological approaches, elaboration of the models for the formation of the legal consciousness of would-be legal professionals. The approaches according to which the formation and development of the legal consciousness of would-be lawyers is carried out taking into account the general regularity of human functioning and development. The professional and personal development of a would-be lawyer in a higher educational institution is analyzed, which should not have a discrepancy in different courses, since the nature of interactions between the structural components of legal consciousness, a lawyer at different stages of training has its own specifics.

The main attention in solving the problem of the development of legal consciousness is aimed at disclosing its essence, structure, internal organization, interrelation of components, its integration, system of factors; mechanisms that ensure the integrity of the system for detecting stages, trends and prospects of its development. The development of legal consciousness is determined by the typology and specifics of professionally determined tasks, the general level of development of legal consciousness of students, which essentially governs the effectiveness of learning and future professional activities.

A lawyer's consciousness gets distinct depending on the legal activity experience and personal characteristics (active involvement, emotional-volitional sphere, motivation for achieving success, internality, reflexivity, intellect). The peculiarities of the manifestation of subjectivity in the professional activity of a lawyer are determined by the content of the self-concept. Thus, the formation of the personality of a lawyer is not only the goal, but also the most important condition for the development of legal consciousness of the would-be specialists. The development of legal consciousness is a natural process of changes expressed in quantitative, qualitative and structural transformations of the personality and the psychological conditions for the development of legal consciousness of the would-be lawyers is a set of activities in the educational process that ensure the achievement of the required level of legal awareness by future specialists.
Постановка проблеми. Демократизація сучасного українського суспільства і гуманізація освіти висувають підвищені вимоги до правосвідомості майбутніх юристів. Від цього залежить їх соціально-правова, громадянська активність, готовність брати участь у зміцненні законності та правопорядку. Майбутній юрист повинен усвідомлювати свої інтереси, знати права i вміти захищати їх законними засобами, виконувати обов'язки, поважати права й інтереси інших громадян, тому правосвідомість студентів-юристів має розвиватися у вузі під впливом цілеспрямованих дій організованого характеру.

Мета статті - розглянути аспекти формування правосвідомості як багаторівневе утворення, що має свої змістовні і динамічні характеристики. Проаналізувати відносно стійкий процес і дослідити цей феномен, оскільки він схильний до внутрішніх змін.

Аналіз останніх досліджень. Аналіз сучасних досліджень у галузі загальної та юридичної психології (О.М. Бандурка, В.І. Барко, С.П. Бочарова, 
В.Л. Васильєв, О.В. Землянська, В.С. Медвєдєв, О.Р. Ратінов, В.В. Романов, О.В. Тимченко) свідчить про значну наукову актуальність вирішення проблеми правосвідомості особистості, зокрема правосвідомості фахівця юридичного профілю. Правосвідомість сучасного юриста, на думку цих авторів, слід розглядати як особливу форму свідомості, яка у зв'язку з впливом низки об'єктивних (соціальних) і суб'єктивних (психологічних) чинників складається із комплексу базових правових понять.

У механізмі правового впливу на особистість юриста надзвичайно важливу роль відіграє правосвідомість. Вона посідає проміжне місце серед елементів свідомості, оскільки формується у людей під впливом різних чинників, у тому числі правових. Правосвідомість при всій iii різноманітності й недосконалості виступає як засіб регулювання суспільних відносин особистість - право [4].

За визначенням О.М. Бандурки, С.П. Бочарової, О.В. Землянської, правова самосвідомість розглядається як сфера індивідуальної свідомості, що відбиває правову дійсність у формі юридичних знань, оцінного ставлення до права і практики його застосування, правових установок і ціннісних орієнтацій, що регулюють людську поведінку в юридично значущих ситуаціях [3]. На думку В.Л. Васильєва, правосвідомість - це система ідей, уявлень, емоцій та почуттів, які виражають ставлення індивіда, групи, суспільства до права і діяльності, пов'язаної з правом. У ній відображена правова дійсність у вигляді знань про право, осмислення того, що є правом, яким воно було (ставлення до права минулих років) і яким має бути (ставлення до майбутнього права), а також у вигляді правових настанов поведінки як реакції на оцінку чинного права, роботу правозастосовних органів. Правосвідомість має бути властива не тільки творцям юридичних норм, законодавцям, а й усім громадянам держави [4].

Виклад основного матеріалу статті. Свідомість юриста здатна, як і свідомість загалом, відображати об'єктивну дійсність, властиву тільки конкретній особистості, реалізуючись у теоретичних, пізнавальних, оціночних діях, в освіті, вихованні та саморозвитку. Вона дозволяє суб'єкту самовизначитися, сформувати своє ставлення до юридичної діяльності, до себе як фахівця іншим суб'єктам, долати окремі професійні труднощі і вирішувати для себе проблему сенсу вибору юридичної професії.

На думку Р.С. Байніязова, «специфічною особливістю правової свідомості майбутнього юриста $\epsilon$ його становлення і розвиток у процесі навчально-професійної підготовки майбутнього фахівця» [5].
У сучасних дослідженнях представлені моделі дослідження категорії правової свідомості як різновиду свідомості, які здебільшого носять описовий характер. Крім того, не вирішено питання про умови розвитку і формування правової свідомості. Це пояснюється тим, що значна кількість досліджень несе на собі відбиток професіографічного підходу. Проблему правосвідомості особистості розглядали А.М. Бандурка, С.П. Бочарова [7], В.Л. Васильєв [10], Е.В. Землянська [7], М.І. Еникеев [15], Г.Х. Єфремова [16], П.В. Макаренко [23] та інші.

Оскільки правова свідомість $є$ складним феноменом, який функціонує у системі взаємодії внутрішніх (психічних) і зовнішніх (соціальних) факторів, виникає необхідність вивчення іiі розвитку в системі міжфункціональних зв'язків, які об'єднують всі елементи в єдине цілісне утворення. Істотні кроки у розкритті системної природи психіки зроблені Б.Г. Ананьєвим [2], Л.С. Виготським [11], А.Н. Леонтьєвим [21], А.Р. Лурією [22] та іншими.

У нашому дослідженні ми використовуємо підхід, згідно з яким становлення і розвиток правосвідомості майбутніх юристів здійснюється 3 урахуванням загальної закономірності функціонування і розвитку людини - нерівномірності змін і стадій розвитку різних систем онтогенезу [2].

Головну увагу при вирішенні проблеми розвитку правосвідомості майбутніх юристів ми зосередили на розкритті їі сутності, структури, внутрішньої організації, взаємозв'язку компонентів, іiі інтеграційній системі чинників; механізмів, що забезпечують цілісність системи виявлення етапів, тенденцій і перспектив іiі розвитку. Розвиток правової свідомості майбутніх юристів визначається типологією і специфікою професійно зумовлених завдань. Загальний рівень розвитку правової свідомості студентів впливає на ефективність навчальної та майбутньої професійної діяльності. Свідомість юриста різниться залежно від досвіду юридичної діяльності та особистісних характеристик (активність, емоційно-вольова сфера, мотивація досягнення успіху, інтернальність, рефлексивність, інтелект). Як зазначала Н.Ю. Евплова, «особливості вияву суб'єктності у професійній діяльності юриста зумовлені змістом Я-концепції» [14]. Отже, формування особистості юриста - не тільки мета, але й найважливіша умова розвитку правосвідомості майбутніх фахівців.

Основою цього розвитку є системний, діяльнісний та особистісно-орієнтований підходи до організації педагогічного процесу у вузі. Системність в організації процесу формування правосвідомості виявляється у цілісності його внутрішньої структури: мета - зміст - засіб - результат. 
Системний підхід до організації процесу формування правосвідомості орієнтує на те, що право як система має вивчатися цілісно і систематично відповідно до іiі внутрішньої логіки. Оскільки людина сприймає світ не окремо через думки, переживання, дії, тому знайомити іiї з правовими явищами слід цілісно - через світ понять, переживань і практичних дій. У цьому випадку, на думку Р.С. Байніязова, «буде відбуватися комплексний вплив на всі ії̈ структурні компоненти правосвідомості: когнітивний, емоційно-ціннісний і поведінковий» [5]. Діяльнісний підхід до процесу формування правосвідомості особистості майбутнього юриста вимагає спеціальної роботи з організації навчальної діяльності студентів.

Особистісно-орієнтований підхід «орієнтації», на думку С.А. Дніпрова, $\epsilon$ «найважливішою психологічною ідеєю, яка відбиває сучасні суспільні тенденції у побудові і функціонуванні системи освіти, - це гуманізація освіти». 3 точки зору автора, «вона розглядається як переорієнтація на особистісну спрямованість, як процес i результат розвитку і самоствердження особистості, як засіб ії соціальної стійкості і захисту в умовах ринку» [13].

Гуманістична спрямованість змінює уявлення про цілі освіти в сторону гармонійного розвитку особистості. В умовах кардинальних змін в ідеології, суспільного життя воно бачиться по-новому. Нині цілі освіти передбачають розвиток тих здібностей особистості, які потрібні їй і суспільству.

Як зазначає С.П. Іванова, «розвиток правосвідомості у студентів вищих навчальних закладів $\epsilon$ керованим процесом, який спрямований на формування особистості в освітньому процесі». Автор зазначає, що «управління розвитком правової свідомості студентів включає такі ланки: формування цілей, програмно-цільове планування, прийняття рішень, контроль виконання рішень, коригування діяльності, аналіз зворотного зв'язку, визначення ефективності виконаної роботи» [18].

3 метою раціоналізації і визначення психолого-педагогічних умов розвитку правової свідомості студентів вищих навчальних закладів нами розроблена теоретична модель розвитку правової свідомості майбутніх юристів (рис. 1). Модель містить такі компоненти: цільовий компонент - соціальне замовлення, мета, основні підходи і принципи формування правової свідомості майбутнього юриста в умовах вузу - гуманізація, системність, комплексність, безперервність, єдність теорії і практики; змістовний компонент, який містить сфери формування правосвідомості: спілкування, діяльність, самосвідомість, психолого-правовий клімат, правове навчання і виховання, соціальну та психологічну підтримки, профілактику і подолання деформації; інструментальний компонент - містить форми, методи і засоби правового навчання, виховання і розвитку особистості; контрольно-оцінний компонент - критерії сформованості правосвідомості - правові знання, ставлення до права; правові установки; правову поведінку і рівні розвитку правової свідомості, які тісно пов'язані між собою і впорядковані один щодо одного.

Інструментальний компонент теоретичної моделі (рис. 1) включає методи і механізми розвитку правової свідомості студентів. Відповідно до характеру пізнавальної діяльності студентів застосовуються такі методи: пояснювально-ілюстративний (інформаційно-рецептивний), репродуктивний, проблемний виклад, частково-пошуковий, евристичний, дослідницький.

3 метою вивчення студентів, вирішення проблем психологічного характеру використовуються психодіагностика, психокорекція, психологічне консультування. Розвиток правосвідомості студентів може бути успішно здійснено тільки на основі комплексного підходу до розвитку особистості, за якого забезпечується єдність навчання i виховання, навчальної та позанавчальної діяльності, змісту, форм і методів роботи зі студентами.

У реалізації теоретичної моделі розвитку правової свідомості студентів істотне значення має контрольно-оцінний компонент. Про рівень розвитку правової свідомості студентів можна судити з об'єктивних і суб'єктивних показників. Об'єктивними показниками правової вихованості є показники навчальної діяльності студента (успішність, дисципліна, активність у різних сфеpax життя, правові знання, вміння). Суб'єктивні показники правової вихованості - це ставлення до права, оцінка права, правові цінності, правові установки, мотиви.

Розвиток правосвідомості майбутніх юристів розглядається нами 3 двох відносно самостійних сторін: функціональної та змістовної. Тому була розроблена функціональна (рис. 2) і змістовна (рис. 3) моделі формування правосвідомості майбутніх юристів.

Функціональна модель формування правосвідомості майбутніх юристів включає в себе такі елементи: структурні компоненти правосвідомості (когнітивний, емоційно-вольовий, мотиваційний і регуляторний), цілі та етапи формування правосвідомості, основні умови, психологічні засоби формування правосвідомості, критерії оцінки сформованості правосвідомості. Функціональна модель містить основні сфери, методи, засоби, які сприяють розвитку правосвідомості.

Мета конкретизується через певні завдання: змістом процесу розвитку правосвідомості студентів є становлення громадянина 3 розвиненою правовою культурою, формування системи пра- 


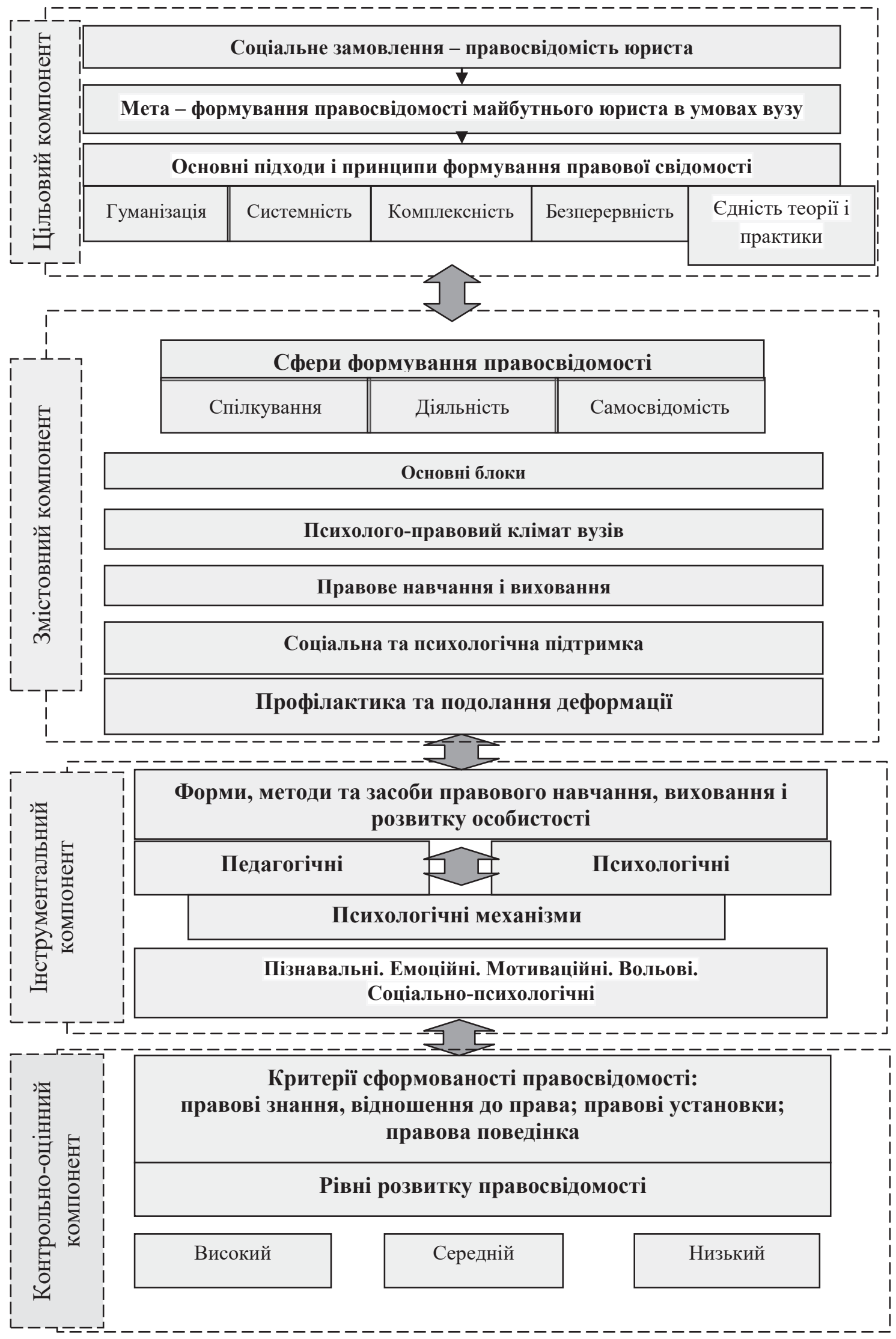

Рис. 1. Теоретична модель формування правосвідомості майбутніх юристів 


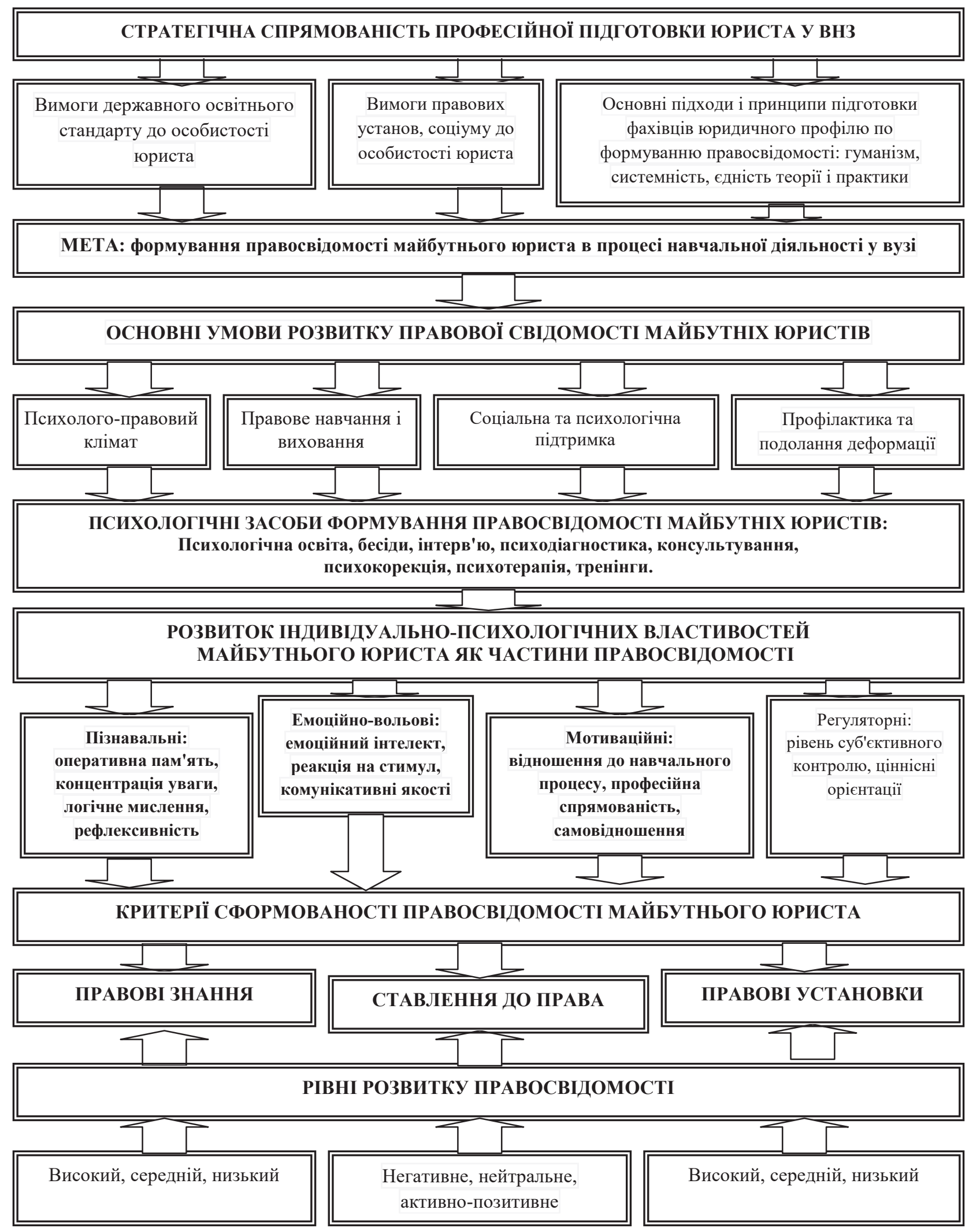

Рис. 2. Функціональна модель формування правосвідомості майбутніх юристів 


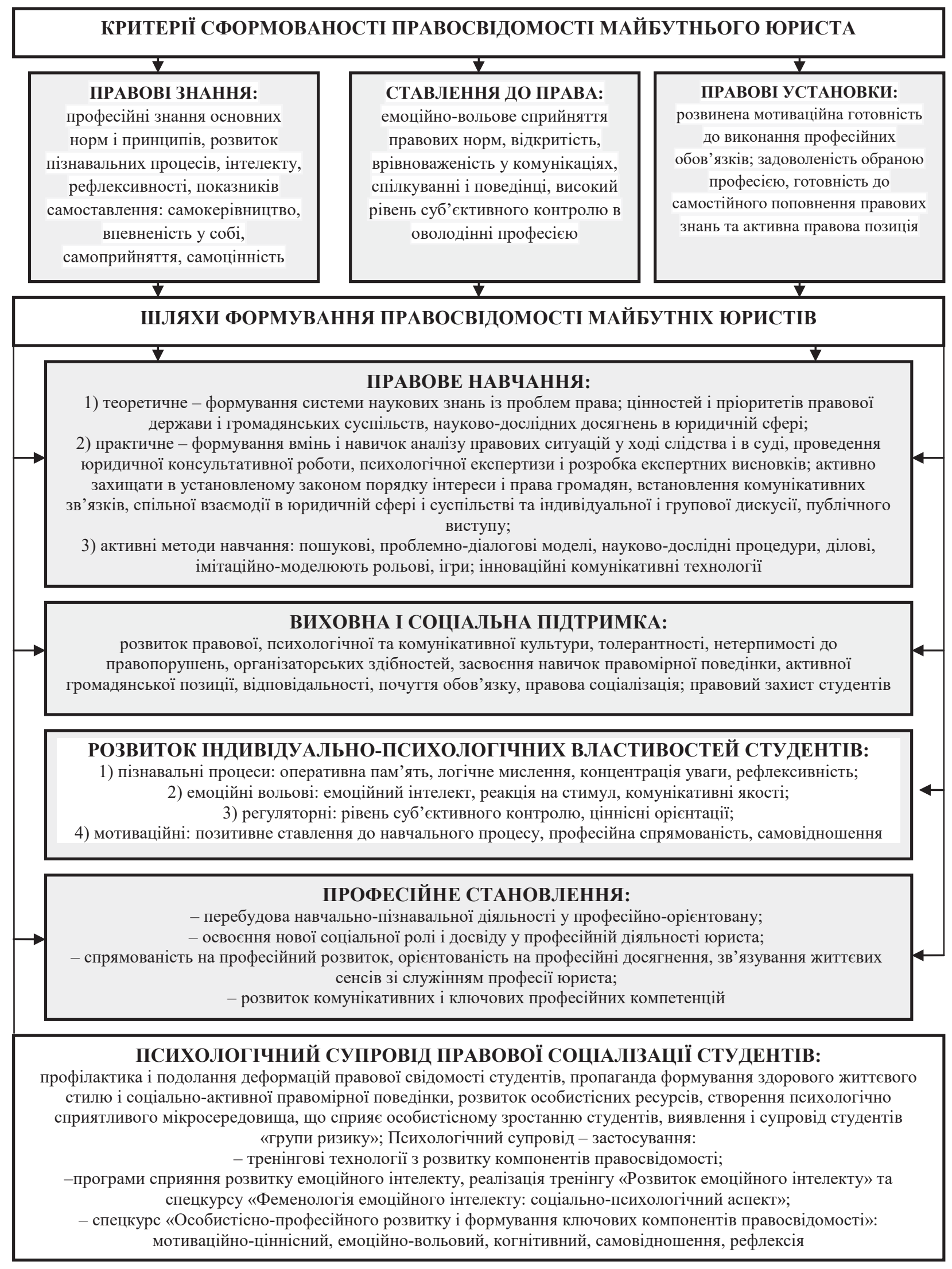

Рис. 3. Змістовна модель формування правосвідомості майбутніх юристів 
вових знань, формування цінностей і пріоритетів правової держави і громадянського суспільства, формування зважених потреб, почуття обов'язку і відповідальності. Метою процесу розвитку правосвідомості майбутнього фахівця є формування переконань, установок і навичок соціально-активної правомірної поведінки.

Функціональна модель $€$ системою (див. рис. 2). Системність як властивість запропонованої нами моделі передбачає іiі єдність, цілісність за наявності диференціації елементів. Усі елементи функціональної моделі формування правосвідомості взаємозумовлені і спрямовані на системоутворюючі чинники, якими $€$ цілі формування правосвідомості. Показниками ефективності функціональної моделі $є$ критерії оцінки сформованості правосвідомості. Залежно від результатів цієї оцінки можна коригувати зміст правової освіти та компоненти формування правосвідомості.

У змістовній моделі (див. рис. 3) виділені провідні компоненти формування правосвідомості майбутніх юристів: правові знання, ставлення до права, правові установки, а також запропоновано шляхи формування правосвідомості майбутніх юристів: правове навчання, виховна та соціальна підтримка, розвиток індивідуально-психологічних властивостей студентів, професійне становлення, психологічний супровід правової соціалізації студентів.

Правове навчання у вузі має бути спрямоване на формування правової компетентності студентів. Головним підсумком вивчення права має стати розуміння пріоритетності правових норм, особливої значимості права і освоєння правових засобів його дії в сучасному суспільстві.

Основними критеріями розвитку правової свідомості студентів є правові знання, правова обізнаність, ставлення до права, правові переконання, ціннісні орієнтації, правові установки і правова поведінка. Кожен із названих критеріїв необхідний як показник, який виявляються у рівнях розвитку (низький, середній, високий). Вирішальним критерієм правової свідомості студентів $\epsilon$ їхня правова поведінка (правомірна чи протиправна).

У кожному з розглянутих компонентів розроблених моделей розвитку правосвідомості студентів психологічний аспект знаходиться в єдності із педагогічним аспектом. Розвиток правосвідомості студентів здійснюється за безпосередньої участі таких психічних явищ, як відчуття і сприйняття, увага і уява, пам'ять і мислення, що впливають на психологію пізнавальних процесів особистості студента. Вчинками людини керують психологічні властивості і стани особистості: здібності, потреби, мотиви, воля, почуття, емоції, характер, ціннісні орієнтації. Правосвідомість активно розвивається у спілкуванні з іншими людьми, виконуючи правові функції, регулюючи свою правову поведінку.

Висновки. 1. Правосвідомість є складним особистісним утворенням, відображає дійсність у формі правових знань, оцінного ставлення до права і практики його застосування, правових установок і ціннісних орієнтацій, що регулюють поведінку особистості в юридично значимих ситуаціях. Формування правосвідомості майбутніх юристів зумовлено постійною взаємодією двох факторів: об'єктивних (соціальних) і суб'єктивних (індивідуально-психологічних). Аналіз об'єктивних чинників формування правосвідомості як домінуючий детермінант цього процесу дозволяє виділити систему таких соціальних явищ: соціально-економічна структура суспільства, рівень суспільної правосвідомості, існуючі у суспільстві норми моралі і права, система загальної та професійної юридичної освіти. Найважливішими суб' єктивно-психологічними факторами розвитку професійної правосвідомості особистості студента-юриста є система засвоєних ним правових понять, принципів, норм моралі і права, на яких заснована психологічна структура його майбутньої професійної діяльності.

2. Розвиток правової свідомості - це багатогранний і багаторівневий, соціально детермінований процес, який здійснюється разом із розвитком особистості і виявляється у діяльності, поведінці i відносинах людини 3 іншими людьми й навколишнім світом загалом. Розвиток індивідуальної правосвідомості спрямовано по лінії сходження від менш усвідомлених до більш усвідомленим форм правової саморегуляції.

3. Вдосконаленню розвитку правової свідомості майбутніх юристів сприяє цілеспрямована реалізація моделі розвитку правосвідомості, яка заснована на єдності зовнішніх і внутрішніх умов, включно з цільовим, змістовним, інструментальним і контрольно-оцінним компонентами.

\section{ЛІТЕРАТУРА}

1. Ананьев Б.Г. Избранные психологические труды. Москва : Педагогика, 1980. 230 с.

2. Байниязов Р.С. Правосознание: психологические аспекты. Изв. вузов. Правоведение. Санкт-Петербург, 1998. № 3. С. 16-21.

3. Бандурка А.М., Бочарова С.П., Землянская Е.В. Юридическая психология : учебник. Харьков : Изд-во Нац. ун-та внутр. дел, 2001. 640 с.

4. Васильев В.Л. Юридическая психология: 3-е изд. СПб. : Питер, 2000. 624 с. 
5. Выготский Л.С. Психология развития как феномен культуры / под ред. М.Г. Ярошевского. Москва, 1996. $281 \mathrm{c}$.

6. Днепров С.А. Педагогическое сознание: теория и технологии формирования у будущих учителей : монография. Екатеринбург : Урал. гос. пед. ун-т, 1998. 298 с.

7. Евплова Н.Ю. К вопросу о понятии правосознания. Вестник Волжского университета им. В.Н. Татищева. Тольятти, 1998. Вып. 2. С. 31-40.

8. Еникеев М.И. Основы юридической психологии : учебник. М. : Норма, 2009. 448 с.

9. Ефремова Г.Х. Проблема общественного мнения в юридической психологии. Москва : Изд-во НИИ пробл. укрепления законности и правопорядка, 1998. 118 с.

10. Иванова С.П. Особенности правового сознания студенческой молодежи: политико-психологический аспект : дис. канд. психол. наук. СПб., 2003. 259 с.

11. Леонтьев А.Н. Деятельность. Сознание. Психика. Москва : Наука, 1982. 340 с.

12. Лурия А.Р. Язык и сознание. Ростов-на-Дону : Феникс, 1998. 416 с.

13. Макаренко П.В. Соціально-психологічні аспекти формування особистості фахівця системи ОВС. Вісник Університету внутрішніх справ. 1999. Вип. 5. С. 254-259.

14. Муслумов Р.Р. Психолого-педагогические условия формирования правового сознания будущих учителей. Вестник Бурятского государственного университета. Теория и методика обучения, 2007. Вып. 10 С. 216-221.

15. Фаттахова Г.Р. Формирование когнитивных составляющих правосознания студентов педагогических вузов : дис. канд. психол. наук. Уфа, 2007. 180 с.

\section{REFERENCES}

1. Ananiev B.G. (1980) Izbrannie psykhologicheskie trudy [Selected psychological works]. M. : Pedagogika [in Russian].

2. Bayanizov R.S. (1998) Pravosoznanie: psykhologicheskie aspekty [Legal consciousness: psychological aspects]. SPb. : Izv. vuzov. Pravovedenie [in Russian].

3. Bandurka A.M. (2001) Yuridicheskaya psykhologia : Uchebnik [Legal psychology : Textbook]. A.M. Bandurka, S.P. Bocharova, E.V. Zemlyanskaya. Kharkiv : Publishing House of Internal Affairs University [in Russian].

4. Vasiliev V.L.(2000) Yuridicheskaya psykhologia [Legal psychology]. SPb. : "Piter", 2000.

5. Vygotsky L.S. (1996) Psyhologia razvitia kak phenomen kulturi / pod red. M.G, Yaroshevskogo [Psychology of development as a phenomenon of culture]. M. : Voronezh [in Russian]

6. Dneprov S.A. (1998) Pedagogicheskoe soznanie: theoria I tekhnologia formirovania u budushchih uchitelei : monografia [Pedagogical consciousness: theory and technologies of formation in would-be teachers : monograph]. Yekaterinburg: The Urals State Pedagogical University [in Russian].

7. Evplova N.Yu. (1998) K voprosu o ponyatii pravosoznania [Pertaining the issue of the concept of legal consciousness]. Tolyatti Bulletin of the Volzhsky Univesity named after V.N. Tatishchev [in Russian].

8. Enikeyev M.I. (2009) Osnovy yuridicheskoy psykhologii : Uchebnik [Fundamentals of legal psychology : Textbook]. M. : Norma [in Russian].

9. Efremova G.H. (1998) Problema obshchestvennogo mnenia v yuridicheskoi psykhologii [The problem of public opinion in legal psychology]. M. : Publishing House of the Research Institute for problems of strengthening the rule of law and order [in Russian].

10. Ivanova S.P. (2003) Osobennosti pravovogo soznania studencheskoi molodezhi: politico-psykhologicheskii aspect : dis. kand. psykholog. nauk [Features of the legal consciousness of student youth: political and psychological aspect : dis. Cand. psychol. Sciences]. SPb. [in Russian].

11. Leontiev A.N. (1982) Deyatelnostj. Soznanie. Psykhika. [Activity. Consciousness. Psychic setup.]. M. : Nauka [in Russian].

12. Luria A.R. (1998) Yazik i soznanie [Language and consciousness]. Rostov-na-Donu : Fenix [in Russian].

13. Makarenko P.V. (1999) Sozialno-psykhologichni aspekti formuvannia osobystosti fahivzya sistemy OVS [Social and psychological aspects of the personality formation of a specialist within the OVS system] / Bulletin of Internal Affairs. Issue 5 [in Ukrainian].

14. Muslumov R.R. (2007) Psihologo-pedagogicheskie uslovia formirovania pravovogo soznania budushchih uchitelei [Psychological and pedagogical conditions for the formation of the legal consciousness of would-be teachers]. Bulletin of the Buryat State University. Theory and methods of Teaching Issue 10 [in Russian].

15. Fattakhova G.R. (2007) Formirovanie kognitivnih sostavlyayushchih pravosoznania studentov pedagogicheskih vuzov : diss. kand. psihol. nauk: [Formation of cognitive components of legal consciousness of pedagogical university students : dis. Cand. psychol. Sciences]. Ufa [in Russian]. 